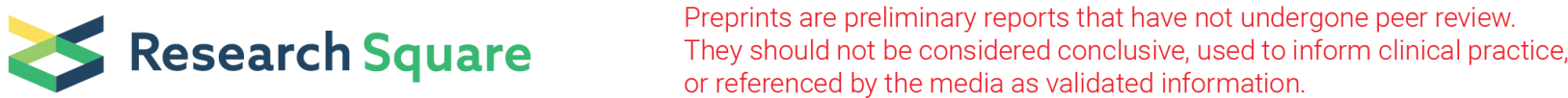

\section{Spatio-temporal Clusters of Health Workforce Distribution in Sichuan Province, China: a county-level analysis}

\author{
Ning Zhang \\ Xi'an Jiaotong University \\ Wei Ning \\ Xi'an Jiaotong University \\ Tao Xie \\ Xi'an Jiaotong University \\ Jinlin Liu \\ Stanfrod University \\ Bin Zhu \\ City University of Hong Kong \\ Rongxin $\mathrm{He}$ \\ Xi'an Jiaotong University
}

Xue Wang

The Second Affiliated Hosptial of Xi'an Jiaotong University

Ying Mao (D mao_ying@mail.xjtu.edu.cn )

Xi'an Jiaotong University https://orcid.org/0000-0002-8271-2524

\section{Research article}

Keywords: health workforce, Spatio-temporal analysis, Spatial autocorrelation analysis, Space-time scan analysis, health technicians, licensed doctor, registered nurse, intern, Sichuan

Posted Date: February 12th, 2020

DOI: https://doi.org/10.21203/rs.2.23389/v1

License: (c) (1) This work is licensed under a Creative Commons Attribution 4.0 International License. Read Full License 


\section{Abstract}

Background

The health workforce is a key determinant in achieving health equity. As a southwestern province of China, Sichuan confronted with the geographical variation of health workforce in recent years. The misdistribution of health workforce in Sichuan is severe for its complex terrain, uneven population distribution and huge economic differences. The study of Sichuan province is of great significance to other regions of China.

Methods

This study applied time-series analysis, spatial autocorrelation and space-time scan analysis to explore and visualize the spatial changing patterns of different types of health workforce (health technicians, licensed doctors, registered nurses, pharmacists, technologists, and intern) at the municipal and county level in Sichuan.

Results

The box plots displayed the temporal trend of health workforce from 2009 to 2018 via the county-level data. All types of health workforce were in rising generally especially the registered nurses. The space-time analysis and Global Moran' I revealed the distinctive geographical clusters among all the counties. The local Moran' I detected that HH clusters mainly in the capital and some rich places of Sichuan, while some mountain areas in eastern Sichuan displayed LL clusters. Four main findings should be paid attention to the whole health workforce of Sichuan province had an upward trend. Comparing with other provinces, the growth rate also was in a high rank; the areas with the scarcest resources were eastern place, including areas of Tsinling Mountains, YunnanGuizhou Plateau, Hengduan Mountains and the transition zone of mountains and basins; misdistribution of health workforce had two levels, among the province and cities; the Qinghai Tibet Plateau has enough intern while being short of other health technicians.

Conclusions

The policies makers should pay more attention to the eastern Sichuan. As to the intern-related policies, the primary health tasks did not achieve, Qinghai Tibet Plateau areas needed to find practical ways to attract the interns

\section{Background}

Health equity is one of the heated issues among the health systems and an important factor that should be considered when it comes to policymaking, as its fundamental function is to protect health benefits from inequity such as misdistribution of health resources. The World Health Organization (WHO) had a long history of improving health equity integrating health equity into policy decision-making [1], implementation and monitoring action [2]. As a crucial component of health resources, the health workforce is a key determinant in achieving health equity.

In 2015, the United Nations (UN) formally announced the sustainable development goals (SDGs) at the UN summit. The health workforce is playing an important part in achieving SDGs. Effective management of health workforce was one of the 13 targets in SDGs. WHO also launched several reports of health workforce about improving professional education [3], promoting universal health coverage and improving access to key maternal and new-born health [4, 5]. Many previous studies have shown the relationship between qualified health workforce and health outcomes. WHO revealed that the negative correlation between the health workforce with maternal and child health [6], while at the same time, the WHO developed a framework to monitor and evaluate the health system through some indicators, including the health workforce indicators [7].

As the biggest developing country in the world, China is confronted with the geographical variation of health workforce among different provinces. The number of health technicians (HT) per 1000 population went up from 4.15 to 6.50 according to China Health Statistical Yearbook and China Health and Family Planning Yearbook from 2009 to 2017, with the annual average growth rate being 5.77\%. However, different provinces had quite different quantities and quality (See Additional file 1: Growth of the number of health workforce per 1000 population in China). Same results have also been found in other counties, namely the United Kingdom [8], Australia [9], Spain [10], Thailand [11], South African [12], Brazil [13], India [14], Indonesia [15], Cameroon [16]. Chen found that the highest growth rate of urban community health service was in Beijing, Shandong, and Zhejiang [17]. Anand et al. discovered that urban-rural disparities were the main cause of inter-county inequality [18]. Sichuan province is located in southwestern China, which capital is Chengdu. The complex terrain, uneven population distribution and huge economic differences caused the misdistribution of health workforce. The research of Sichuan is important for China. Ren found that health human resources explained part of the difference in maternal mortality rate between minority and non-minority counties in Sichuan [19]. Sichuan province has issued a series of policies and measures to strengthen the construction of health human resources team, such as increasing investment in health human resources, strengthening education and training, and promoting various talent projects, which had achieved effective results.

A large number of researchers have studied the distribution of health workforce in China or Sichuan. On the one hand, some of them mainly focused on the equity of health workforce through temporal analysis. Xie found the health workforce tended to concentrate in richer regions by the concentration index from 2009 to 2015, which had become an increasingly obvious trend [20]. The research of Zhu revealed the rapid growth of health workforce from 2004 to 2014 by Theil index, the results showed that the index decreased continually during the research period [21]. Chen explored the equity of health workforce allocation of minority regions in Sichuan province, which used using coefficients of Inter-Individual differences and Individual-Mean differences. On the other hand, some scholars focused on exploring the determinants of the distribution of health workforce to research health workforce equity. Liu analysed the data of western China, finding that job mobility behaviour, job satisfaction, work stress, and turnover intentions are correlated with the distribution of health workforce among 
cities and villages [22-24]. Xu conducted a longitudinal study in Sichuan about current and future career development of health workforce, which revealed that education level, income, gender imbalance would influence job choice [25].

To conclude, the majority of previous research emphasized the health workforce equity and its determinants from the perspective of temporal analysis, however, there was lacking analysis from the aspect of spatial side and comparing different types of health workforce. Only Zhu analysed the health workforce distribution of China [21,26]. However, the provincial units' data were inaccurate when conducting spatial analysis. At the same time, the attraction and retention policies should be formulated and implemented respectively according to the different health workforce and units. Sichuan is the junction of different terrains, the experiences of Sichuan could be extended to other provinces. Therefore, the goal of his research is to study spatio-temporal characteristics of health workforce distribution in the Sichuan province of China. Specifically, first, we conducted and visualize the temporal analysis of the health workforce in Sichuan. Second, the analysis of the spatial characteristics would be included in articles. Third, we would analyse spatial clusters of health workforce. Based on the research results, we would like to propose corresponding policies and strategies about the distribution of health workforce.

\section{Methods}

\subsection{Study area}

Sichuan province, well-known for its peppery and spicy cuisine, has an area of $486,000 \mathrm{~km}^{2}$ and a population of 83.41 million in 2018 . There were 21 municipal-level areas, containing 183 county-level districts of Sichuan province. Chengdu is the capital of Sichuan. This study applied both level data with different methods.

Sichuan province has extremely complex terrain, which spans several geomorphic units, such as the Qinghai-Tibet Plateau, Hengduan Mountains, YunnanGuizhou Plateau, Tsinling Mountains, and Sichuan Basin. The basin area was surrounded by various mountains, displaying a relatively developed level in the aspects of the economy, education, medicine et al. Figure 1 showed the map of Sichuan. This study would summarize and analyse the results from the perspective of the geographic unit by applying spatial analysis methods.

\subsection{Study Setting and Data Resources}

The health workforce in China is composed of the health technicians (HT), village doctors \&assistants, other technical personnel, administrative personnel, and logistics technical workers. Different types of health workforce played a unique role in the operation of the health system. Technically, the health workforce only refers to HT, which is mainly functioning as health professionals, containing licensed doctors (LD), registered nurses (RN), pharmacists (PH), technologists (TE) and interns (IN) [27]. HT accounted for three-fourths of the whole health workforce. The specific classification of health workforce would be found in Additional file 2. Above all, the analysis of TP, LD, RN, pharmacist, technologist, and interns were included in this study. Regarding the measurement of indicators, the total number of health workforce, the number of health workforce per 1000 population (the analysis of the number of health workforce per square kilometre is in Additional file 7) were displayed by different methods. The first indicator was obtained from the yearbook. Later one was calculated according to the absolute number of health manpower, population, and area of different counties.

The study used the county-level year-end data in Sichuan during 2009-2017 with 21 municipal areas, autonomous prefecture, and 183 counties. 2009 is the first year after Chinese new medical reform, while various policies were formulated and promulgated after that [28]. The data were collected from Sichuan Health Statistics Yearbook, Sichuan Health and Family Planning Statistical Yearbook, which both published by the Health Commission of Sichuan province, Sichuan Statistical Yearbook published by Sichuan Provincial Bureau of Statistics, and China County Statistical Yearbook published by National Bureau of Statistics of China. Additional file 3-5 contained the population of counties in Sichuan, the number of health workforce in municipal and county level.

\subsection{Time-Series Analysis}

The time-series analysis illustrated the temporal trend of the number of health workforce per 1000 population in Sichuan province using the county data. On the one hand, the study time (2009-2017) was divided into two equidistant periods, namely 2009-2013 and 2013-2017, which analysed the changing pattern of health workforce. The growth rate at the municipal level was displayed. On the other hand, the box plots were introduced to demonstrate the temporal trend of health manpower by basic statistics, namely maximum, minimum, median, upper quartile, lower quartile and outliers [29, 30].

\subsection{Spatial Clustering Analysis}

Spatial autocorrelation analysis and space-time scan analysis were included in this study to detect the spatial clusters of health workforce distribution. The spatial autocorrelation analysis is defined as "variables negatively or positively associated with themselves over space" [31, 32], which meant whether the existence of variables in one unit has affected the existence of other units, negatively or positively, more or less. The spatial autocorrelation demonstrated the unevenly distributed variables. The spatial autocorrelation could be divided into global or local. More specific details would be elaborated in another subsection below. In addition, the space-time scan analysis would redeem the spatial autocorrelation analysis from lacking temporal analysis.

\subsubsection{Spatial Autocorrelation Analysis}

In order to have some insight into the spatial distribution of health workforce, global Moran's I, local Moran's I and relevant graphic tools were introduced to analyse and visualize the spatial autocorrelation results of the number of health workforce per 1000 population, which have been applied in many studies [21, $26,33,34]$. The global Moran's I and local Moran's I displayed the provincial and county level research respectively. In this study, the global one illustrated the whole autocorrelation of Sichuan province while the local one analysed the specific situation of counties and its effect on surrounding units. According to Cliff and Ord [35, 36], the formula of Moran's I in this paper as follows:

Page $3 / 17$ 


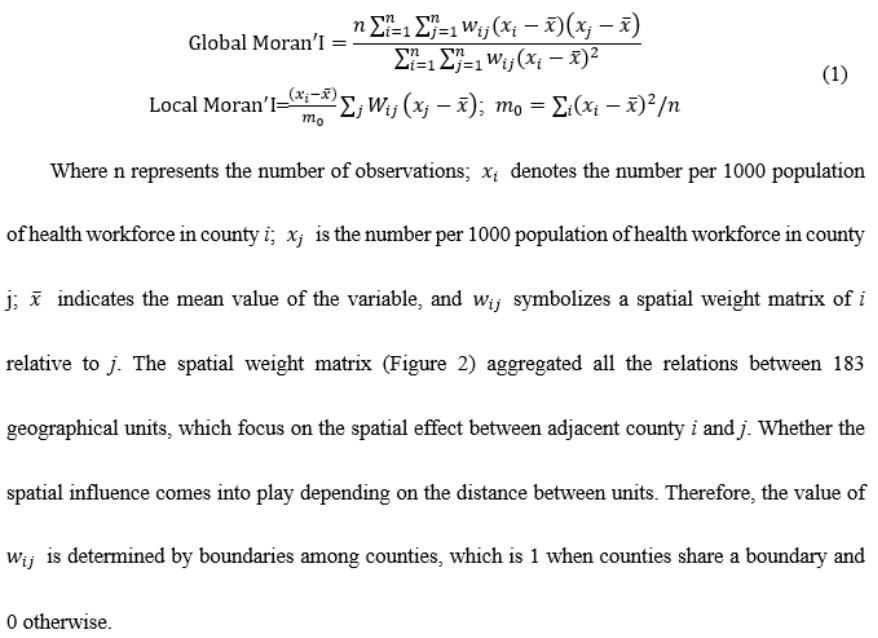

Where $\mathrm{n}$ represents the number of observations; $x_{i}$ denotes the number per 1000 population

of health workforce in county $i ; x_{j}$ is the number per 1000 population of health workforce in county

$\mathrm{j} ; \bar{x}$ indicates the mean value of the variable, and $w_{i j}$ symbolizes a spatial weight matrix of $i$

relative to $j$. The spatial weight matrix (Figure 2) aggregated all the relations between 183

geographical units, which focus on the spatial effect between adjacent county $i$ and $j$. Whether the

spatial influence comes into play depending on the distance between units. Therefore, the value of

$w_{i j}$ is determined by boundaries among counties, which is 1 when counties share a boundary and

0 otherwise.

The range of is Global Moran' I is from - 1 to 1 . In this context, a value near -1 represented spatial aggregation of dissimilarity between counties, which means the low number per 1000 population gathered together and the high ones stuck together in whole geographic units. In contrast, the value surrounding 1 revealed adjoin of low number and a high number in the overall Sichuan province. When the value is around 0 , there is no spatial autocorrelation in the research area, all the number per 1000 population in counties are randomly distributed [37, 38]. In this study, the global Moran's I of health workforce in Sichuan from 2009-2017 are calculated.

Local Moran' I was calculated to detect every signal county' autocorrelation and its relation with vicinage, which had complementary functions against Global Moran' I. The local one could find the regional spatial aggregation, which is helpful in summarizing spatial changing discipline. The range of -1 to 1 is still applicable for local Moran' I and could be understood as the same way as Global Moran' I. There existed four types being detected by local Moran' I, namely high-high $(\mathrm{HH})$, high-low $(\mathrm{HL})$, low-high $(\mathrm{LH})$ and low-low $(\mathrm{LL})$ cluster. The $\mathrm{HH}$ meant the high-value areas that being surrounded by other high-value areas. The other clusters have the same meanings.

For both global and local Moran's I, we would use Monte Carlo randomization (99,999 permutations) to obtain the significance level of the index. The hypothesis would be no spatial agglomeration.

\section{$\mathrm{H}_{0}$ : no spatial autocorrelation}

$\mathrm{H}_{1}$ : spatial autocorrelation

\subsubsection{Space-Time Scan Analysis}

The space-time scan statistic was applied to explore the spatial changing based on the time series of health workforce, which meant the function of the method is to detect the geographical units that had a higher or lower number of health workforce comparing with surrounding areas. In detail, the space-time scan was used through a moving circular column $[39,40]$. The column started scanning all the counties throughout the research period. The variations between inside and outside of the column were calculated by Log-likelihood LLR, the formula is as follows:

$\operatorname{LLR}=\log \left\{(\mathrm{C} / \mathrm{n})^{\wedge} \mathrm{c}[((\mathrm{C}-\mathrm{c})) /((\mathrm{C}-\mathrm{n}))]^{\wedge}((\mathrm{C}-\mathrm{c}))\right\}$

Where $\mathrm{C}$ represents the total number of health workforce, $\mathrm{c}$ denotes the observed cases of health workforce inside the window, and $\mathrm{n}$ represents the expected cases of health workforce inside the window.

The hypothesis would be no difference between the columns among the time. According to the LLR, the higher or lower units would be detected. The classification of clusters contained the most likely cluster, secondary cluster, and others. In this study, the Poisson based analysis was used with Monte Carlo randomization applied to test the cluster significance [41, 42].

$\mathrm{H}_{0}$ : there is no difference between the columns among the time

$\mathrm{H}_{1}$ : there exists difference between the columns among the time

\subsection{Software tools}

The box plot of time-series analysis of health workforce in Sichuan was visualized by Microsoft Excel (Version office 365, Microsoft Corp., Redmond, WA, USA). SPSS (Version 20, IBM Inc., Armonk, NY, USA) was employed to obtain the Pearson chi-square of linear by linear association test. The autocorrelation analysis containing the global Moran's I and local Moran's I were calculated through GeoDa (Version 1.8.61, the University of Chicago, Chicago, IL, USA), while 
the spatial-scan statistics were performed with SatScan (Version 9.5, Kulldorff and Information Management Services, Inc., Boston, MA, USA). At last, ArcGIS (Version 10.0, ESRI Inc., Redlands, CA, USA) was used to visualize the results.

\section{Results}

\subsection{The descriptive analysis}

To gain a more comprehensive and profound understanding of the temporal trends of the health workforce in Sichuan, Table 1 presents the number and growth rate of health workforce per 1000 health population in each municipal units, in which the number and growth rate of the two subsequent time periods (2009-2013, 2013-2018) could be seen. The bold number represented the growth rate with a significant linear trend, which calculated by chi-square and pvalue results for chi-square linear by linear association test (the results could be seen in Additional file 6). On the whole, the health workforce displayed normal and upward trend in most geographical units, while some others revealed the unique characters. For instance, the number of technologists per 1000 population in Neijiang increased by $21.09 \%$ from 0.1250 to 0.2687 in the first period, while the contrast lied in the sharp decrease from 2013 to 2017 with the rate of $-5.28 \%$. The same situation mainly happened to the ID of partial cities. Another noted feature is the unprecedented growth rate such as the RN in Nanchong, where the RN achieved a rate of rising with $21.99 \%$. (Hierarchal maps using the number of health workforce per square kilometre were shown in Additional file 7)

\subsection{Temporal Trends}

Figure 3 used box plots to display the temporal trend of health workforce from 2009 to 2018 via the county-level data. The mild and extreme outliers were identified and marked from the examination of the fence points and data. The median and the lower and upper quartiles were clearly marked with a solid line drawn across the box to locate the median. Clearly, the different health workforce manifested unique characteristics. Regarding the HT, the 25th and 75th percentiles and median experienced a decrease from 2009 to 2010 , followed by a slow rise to 2017, while outlies mainly be discovered in Chengdu. In consideration of LD, the number per 1000 population showed a slow increase in the study period, while the location of medians gradually went down, which represented the relative abundance of lower data. The median of RN displayed a gradual upward trend with distinct characteristics of the expanded box (IQR, interquartile range, the difference between the upper and lower quartile). Similarly, the technologist experienced an increase as well as the box. Surprisingly, the lowest number per 1000 population of $\mathrm{PH}$ remained almost zero in some counties during the whole research period even with the improvement of the whole number. The most prominent feature of interns is the rise in fluctuation. 
Table 1

Growth of number of health workforce per 1000 population in Sichuan 1.

\begin{tabular}{|c|c|c|c|c|}
\hline \multirow[t]{2}{*}{ Region } & Health technicians & Licensed doctor & Registered nurses & Pharmacist \\
\hline & $0^{\text {growth }} 13^{\text {growth }} 17$ & $0^{\text {growth }} 13^{\text {growth }} 17$ & 09growth $13^{\text {growth }} 17$ & $0^{\text {growth }} 13^{\text {growth }} 17$ \\
\hline Chengdu & $7.1835^{8.92 \%^{*}} 10.1087^{2.15 \% *} 11.0083$ & $2.9046^{7.35 \%^{*}} 3.8574^{1.24 \%^{*}} 4.0520$ & $2.5791^{13.06 \% *} 4.2136^{4.60 \%)} 5.0439$ & $\begin{array}{l}0.4617^{5.66 \%^{*}} 0.5756^{-} \\
0.39 \%^{*} 0.5666\end{array}$ \\
\hline Zigong & $3.4715^{7.68 \%} 4.6679^{5.24 \% *} 5.7265$ & $1.5845^{4.52 \%} 1.8911^{2.37 \%} 2.0766$ & $1.2463^{10.69 \%} 1.8711^{7.97 \%^{*}} 2.5428$ & $0.1811^{3.41 \%} 0.2072^{4.46 \%} 0.2<$ \\
\hline Panzhihua & $6.9435^{4.71 \%} 8.3473^{3.24 \%} 9.4835$ & $2.9642^{3.29 \%} 3.3741^{1.81 \%} 3.6252$ & $2.5860^{7.15 \%} 3.4089^{5.74 \%} 4.2623$ & $0.3548^{1.15 \%} 0.3714^{3.82 \%} 0.4 \AA$ \\
\hline Luzhou & $2.4525^{12.13 \% *} 3.8765^{6.55 \%} 4.9965$ & $1.1822^{7.65 \% *} 1.5879^{3.36 \%} 1.8126$ & $0.6299^{22.12 \%^{*}} 1.4011^{13.27 \% *} 2.3061$ & $0.1814^{5.07 \%^{*}} 0.2211^{3.12 \%} 0.2$ \\
\hline Deyang & $3.4485^{7.99 \%^{*}} 4.6906^{5.24 \%^{*}} 5.7534$ & $1.6952^{4.30 \% * 2} 2.0059^{3.42 \%} 2.2948$ & $1.0044^{13.60 \% *} 1.6727^{9.53 \%^{*}} 2.4073$ & $0.2340^{3.58 \%} 0.2694^{3.53 \%} 0.3 \mathrm{C}$ \\
\hline Mianyang & $3.6112^{7.71 \%^{*}} 4.8612^{4.29 \%^{*}} 5.7504$ & $1.6290^{4.88 \%} 1.9708^{2.63 \%} 2.1867$ & $1.0874^{12.65 \%^{*}} 1.7512^{8.52 \% *} 2.4287$ & $0.2557^{2.74 \%} 0.2850^{1.44 \%} 0.3 \mathrm{C}$ \\
\hline Guangyuan & $3.3457^{7.83 \%} 4.5232^{5.16 \% *} 5.5314$ & $1.5708^{4.12 \%} 1.8462^{1.31 \%} 1.9451$ & $0.9795^{12.05 \%^{*}} 1.5438^{10.00 \%} 2.2601$ & $0.2082^{6.09 \%^{*}} 0.2637^{0.25 \%} 0.2$ \\
\hline Suining & $2.6469^{7.92 \% *} 3.5901^{6.06 \%} 4.5429$ & $1.2268^{6.91 \% *} 1.6025^{2.52 \%} 1.7704$ & $0.8011^{12.10 \%{ }^{*}} 1.2649^{10.14 \%^{*}} 1.8612$ & $0.1785^{3.53 \%} 0.2051^{5.04 \%} 0.24$ \\
\hline Neijiang & $2.9004^{7.51 \%} 3.8746^{3.94 \%} 4.5223$ & $1.4568^{2.92 \%} 1.6343^{2.26 \%} 1.7868$ & $0.8078^{13.76 \% *} 1.3529^{9.31 \% *} 1.9318$ & $0.1353^{2.56 \%} 0.1497^{4.81 \%^{*} 0.1}$ \\
\hline Leshan & $3.7344^{6.27 \%^{*}} 4.7624^{4.03 \%^{*}} 5.5783$ & $1.8015^{2.97 \%} 2.0250^{1.41 \%} 2.1418$ & $1.1096^{13.58 \%^{*}} 1.8466^{7.62 \%^{*}} 2.4768$ & $0.2390^{2.88 \%} 0.2677^{1.35 \%} 0.2 \varepsilon$ \\
\hline Nanchong & $2.2754^{9.26 \%^{*}} 3.2427^{8.39 \%^{*}} 4.4754$ & $1.1927^{5.08 \%} 1.4543^{5.25 \%^{*}} 1.7848$ & $0.5420^{21.99 \%} 1.2003^{9.49 \%} 1.7249$ & $0.1294^{2.57 \%} 0.1432^{4.89 \%^{*}} 0.1$ \\
\hline Meishan & $2.8716^{7.19 \%} 3.7913^{6.54 \%} 4.8841$ & $1.4619^{2.75 \%} 1.6298^{2.31 \%} 1.7859$ & $0.7268^{13.13 \%} 1.3680^{11.63 \%^{*}} 2.1246$ & $0.1781^{1.96 \%} 0.1925^{6.82 \%} 0.2$ ؟ \\
\hline Yibin & $2.6384^{9.58 \%} 3.8041^{6.33 \%} 4.8632$ & $1.2623^{4.19 \%} 1.4873^{2.23 \%} 1.6244$ & $0.7945^{15.92 \%} 1.4348^{11.00 \%} 2.1779$ & $0.1340^{4,68 \%{ }^{*}} 0.1610^{5.20 \%} 0.1^{\prime}$ \\
\hline Guangan & $1.8047^{6.97 \%^{*}} 2.3627^{8.23 \%^{*}} 3.2424$ & $0.8360^{4.11 \%^{*}} 0.9819^{4.18 \%^{*}} 1.1567$ & $0.4651^{13.17 \%} 0.7630^{14.32 \%^{*}} 1.3031$ & $0.0860^{2.88 \%} 0.0693^{6.61 \%} 0.12$ \\
\hline Dazhou & $2.1655^{8.86 \%} 3.0412^{5.00 \%} 3.6972$ & $0.9934^{5.73 \%} 1.2413^{2.07 \%} 1.3473$ & $0.5636^{17.23 \% *} 1.0641^{10.05 \%} 1.5610$ & $0.1134^{5.91 \%} 0.1427^{3.29 \%} 0.1 \epsilon$ \\
\hline Yaan & $4.1630^{7.37 \%} 5.5318^{7.03 \% *} 7.2593$ & $1.9884^{3.67 \%} 2.2968^{2.76 \%} 2.5608$ & $1.2023^{14.93 \%} 2.0975^{10.20 \% *} 3.0929$ & $0.2564^{3.72 \%} 0.2969^{2.79 \%} 0.3 \leftleftarrows$ \\
\hline Bazhong & $2.2147^{10.95 \%} 3.3565^{5.61 \%} 4.1754$ & $1.1503^{10.14 \%^{*}} 1.6927^{0.93 \%} 1.7562$ & $0.4595^{21.84 \%} 1.0126^{11.73 \% *} 1.5781$ & $0.1072^{6.88 \%} 0.1399^{5.25 \%} 0.1$; \\
\hline Ziyang & $2.1861^{10.88 \%^{*}} 3.3042^{4.62 \%} 3.9584$ & $1.0720^{6.96 \% *} 1.4029^{1.25 \%} 1.4746$ & $0.5216^{18.74 \%^{*}} 1.0371^{11.33 \%} 1.5930$ & $0.1319^{2.49 \%} 0.1455^{5.97 \%} 0.1 \varepsilon$ \\
\hline Abazhou & $3.8991^{7.05 \%} 5.1196^{7.76 \%^{*}} 6.9027$ & $1.7455^{3.31 \%} 1.9880^{3.56 \%} 2.2863$ & $0.8621^{11.89 \%} 1.3511^{12.67 \%^{*}} 2.1770$ & $0.1177^{13.23 \%} 0.1934^{7.45 \%} 0.2$ \\
\hline Ganzizhou & $4.3656^{2.45 \%} 4.8094^{4.89 \%^{*}} 5.8211$ & $\begin{array}{l}1.7038^{-1.96 \%} 1.5744^{-} \\
0.66 \% 1.5332\end{array}$ & $0.7517^{11.58 \%} 1.1652^{9.44 \%^{*}} 1.6712$ & $0.1153^{7.06 \%} 0.1515^{0.91 \%} 0.1$ ᄃ \\
\hline Liangshanzhou & $2.5590^{6.12 \%} 3.2459^{8.52 \%^{*}} 4.5020$ & $1.2207^{0.38 \%} 1.2395^{2.81 \%} 1.3846$ & $0.9228^{6.55 \%} 1.1896^{12.82 \% *} 1.9269$ & $0.0983^{3.98 \%} 0.1149^{9.81 \%^{*}} 0.1$ \\
\hline Sum & $3.3730^{8.48 \% *} 4.6711^{5.68 \% *} 5.8259$ & $1.5436^{5.38 \% *} 1.9035^{3.03 \%} 2.1450$ & $1.0228^{14.23 \%^{*}} 1.7414^{9.55 \%^{*}} 2.5085$ & $0.1989^{4.46 \%^{*}} 0.2368^{3.69 \%^{*}}$ \\
\hline
\end{tabular}

${ }^{1}$ Growth rates in parentheses, units that displayed a significant linear trend during the sub-period are in bold.

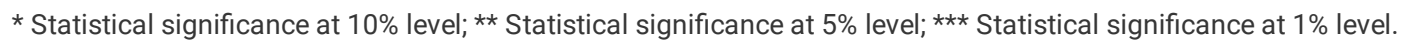

\subsection{Spatial Variations in Temporal Trends}

\subsubsection{Global spatial autocorrelation}

Table 2 illustrated the results of the global spatial autocorrelation of the health workforce and their significance results. From the perspective of the p-value, all the global Moran's I achieved the significance level of 0.001 during the whole study period. The global Moran's I of HT experienced a downward trend, followed by a slight increase in 2016 and 2017, which indicated the weakening of agglomeration. As to LD, the global Moral's I almost remained steady from 2009 to 
2017. Being similar to HT, the global Moral's I of RN displayed an overall downward trend with slight increases in some years. In consideration of pharmacists and technologists, the global Moran's I show the trend of fluctuation. The global Moran's I of interns declined dramatically from 0.647758 in 2009 to 0.544234 in 2013, but the trend reversed and the global Moran's I ended up as 0.675645 in 2017.

Table 2

Global Spatial Autocorrelation Analysis and Significance Test Results of Number of Health Workforce per 1000 population

\begin{tabular}{|c|c|c|c|c|c|c|c|c|c|c|c|}
\hline \multirow[t]{2}{*}{ Year } & \multicolumn{2}{|l|}{ HT } & \multicolumn{2}{|l|}{ LD } & \multicolumn{2}{|l|}{ RN } & \multicolumn{2}{|l|}{$\mathrm{PH}$} & \multicolumn{2}{|l|}{ TE } & \multirow{2}{*}{$\frac{\text { IN }}{\text { Moran' }}$} \\
\hline & Moran's I & $P$ value & Moran's I & $P$ value & Moran's I & $P$ value & Moran's I & $P$ value & Moran's I & $P$ value & \\
\hline 2009 & $0.423706^{\star \star \star 1}$ & 0.000010 & $0.405813^{\star \star \star}$ & 0.000010 & $0.410237^{\star \star \star}$ & 0.000010 & $0.522996^{\star \star \star}$ & 0.000010 & $0.344224^{\star \star \star}$ & 0.00 & 0.6477 \\
\hline 2010 & $0.416124^{\star \star \star}$ & 0.000010 & $0.406026^{\star \star \star}$ & 0.000010 & $0.407913^{\star \star \star}$ & 0.000010 & $0.520049^{\star \star \star}$ & 0.000010 & $0.368554^{\star \star \star}$ & 0.000010 & 0.6178 \\
\hline 2011 & $0.391384^{\star \star \star}$ & 0.000010 & $0.405055^{\star \star \star}$ & 0.000010 & $0.405743^{\star \star \star}$ & 0.000010 & $0.532507^{\star \star \star}$ & 0.000010 & $0.362150^{\star \star \star}$ & 0.000010 & 0.6120 \\
\hline 2012 & $0.391384^{\star \star \star}$ & 0.000010 & $0.397521^{\star \star \star}$ & 0.000010 & $0.379301^{\star \star \star}$ & 0.000010 & $0.469997^{\star \star \star}$ & 0.000010 & $0.289329^{\star \star \star}$ & 0.000010 & 0.6203 \\
\hline 2013 & $0.372937^{\star \star \star}$ & 0.000010 & $0.411781^{\star \star \star}$ & 0.000010 & $0.385633^{\star \star \star}$ & 0.000010 & $0.517939^{\star \star \star}$ & 0.000010 & $0.282955^{\star \star \star}$ & 0.000010 & 0.5442 \\
\hline 2014 & $0.358038^{\star \star \star}$ & 0.000010 & $0.398195^{\star \star \star}$ & 0.000010 & $0.360035^{\star \star \star}$ & 0.000010 & $0.525362^{\star \star \star}$ & 0.000010 & $0.306172^{\star \star \star}$ & 0.000010 & 0.5495 \\
\hline 2015 & $0.344185^{\star \star *}$ & 0.000010 & $0.381742^{\star \star \star}$ & 0.000010 & $0.351074^{\star \star \star}$ & 0.000010 & $0.473459^{\star \star \star}$ & 0.000010 & $0.311680^{\star \star \star}$ & 0.000010 & 0.5878 \\
\hline 2016 & $0.345551^{\star \star \star}$ & 0.000010 & $0.402015^{\star \star \star}$ & 0.000010 & $0.346748^{\star \star \star}$ & 0.000010 & $0.483436^{\star \star \star}$ & 0.000010 & $0.295715^{\star \star \star}$ & 0.000010 & 0.6377 \\
\hline 2017 & $0.347294^{\star \star \star}$ & 0.000010 & $0.406406^{\star \star \star}$ & 0.000010 & $0.352470^{\star \star \star}$ & 0.000010 & $0.487016^{\star \star \star}$ & 0.000010 & $0.319444^{\star \star \star}$ & 0.000010 & 0.6756 \\
\hline
\end{tabular}

1 * means $10 \%$ level statistical significance; ${ }^{* \star}$ means $5 \%$ level statistical significance; ${ }^{\star \star \star}$ means $1 \%$ level statistical significance.

\subsubsection{Local spatial autocorrelation}

Figure 4 presented the results of local spatial autocorrelation with a hierarchical map of the number per 1000 population of the health workforce in 183 counties, which revealed the relative relationship between different geographical units. We classified all the units into five scales by natural break method, which accorded to maximum and minimum of HT, LD, RN, pharmacist, technologist, and interns. The map is a descriptive summary of health workforce. The deeper the red, the higher the number per 1000 population of the health workforce. Take HT in 2009 as an example, the five scales, namely 0-2.4352, 2.4352$3.8973,3.8973-6.1826,6.1826-11.5478$ and $11.5478-19.3185$, distinguished all counties. The northeastern and southeastern areas are the scarcest place, while Chengdu and Panzhihua had relatively rich human resources.

In order to analyse the spatial changing trend, the spatial clusters of all the health workforce in 2009, 2013 and 2017 were visualized in Fig. 5. Different colours symbol different types, only the local Moran's I with significance level below 0.05 could be marked with other colours on the map, otherwise the white blanks. In consideration of HT, the HH clusters were witnessed in the middle and southern areas (12 counties; municipal level: Chengdu and Panzhihua; topographic feature: Sichuan Basin and valley of Hengduan Mountains). Part northeastern and southeastern areas were experiencing LL clusters. (33 counties; Guangan, Suining, Nanchong, Guangyuan, Ziyang, Leshan, Yaan; Tsinling Mountains and Yunnan-Guizhou Plateau); HT areas were found in some rich places in Suining, Nanchong and Liangshanzhou (3 counties; Tsinling Mountains and Qinghai-Tibet Plateau). The situation in 2013 is similar to that in 2009, except that the HL cluster was also detected in Yibin. When it comes to 2017, a county in Abazhou was defined as the LH area.

Speaking of LD, middle area and southern area were found as HH cluster (13 counties; Chengdu, Panzhihua, and Liangshanzhou; Sichuan Basin, the valley of Hengduan Mountains and Qinghai-Tibet Plateau). The other clusters were similar to that of HT in 2009. In 2013, the LL cluster expanded to northwestern territories, which is Ganzizhou in Qinghai-Tibet Plateau, while part of LL clusters in the northeastern area vanished. Furthermore, the northwestern area further expanded. As to RN, the whole cluster situation is similar to HT in 2009, expect that LL clusters in Ganzizhou were detected early. The number of LL clusters in Ganzizhou were gradually increasing in 2013 and 2017.

In term of pharmacist, the $\mathrm{HH}$ clusters were found in middle Chengdu and Panzhihua, while LL area could be witnessed in Sichuan border area (28 counties; Bazhong, Guangan, Dazhou, Yibin, Leshan, Yaan, Liangshanzhou, and Ganzizhou; Tsinling Mountains, Qinghai-Tibet Plateau, and Yunnan-Guizhou Plateau). Xichang was distributed in the HL cluster. As time goes by, the HH clusters and LL clusters both widened to surrounding places in 2013. When it comes to 2017, two special spots were considered as LH and HL area, which respectively located in Abazhou and Ganzizhou.

Considering TE in 2009, HH clusters were located in Chengdu (11 counties, Sichuan Basin), while LL clusters could be detected in northeastern, northwestern and southeastern territories (18 counties, Bazhong, Nanchong, Dazhou, Guangan, Mianyang, Luzhou, Leshan, Liangshanzhou and Ganzizhou; Tsinling Mountains, Qinghai-Tibet Plateau, and Yunnan-Guizhou Plateau). HL clusters were found in Suining, Nanchong, Abazhou, and Liangshanzhou, while LH clusters could be seen in Meishan and Yaan (border with the rich region). In 2013, a new HH cluster was discovered in one county in Abazhou, which expanded to other counties in 2017. A new LH spot was witnessed in Abazhou as well.

Different from other health workforce, interns experienced a unique change. In 2009, the western and middle area had the HH clusters (23 counties; Ganzizhou, Abazhou, and Chengdu; Sichuan Basin and Qinghai-Tibet Plateau). The LL clusters could be seen in Guangyuan, Bazhong, Nanchong, Suining, Guangan, 
Liangshanzhou, Leshan, Yibin and Luzhou (25 counties, Tsinling Mountains and Yunnan-Guizhou Plateau). HL clusters were located in some rich places in Nanchong, Ziyang, Yaan, and Liangshanzhou. LH clusters in Liangshanzhou as well. As time goes by, the HH and LL clusters widened.

\subsection{Space-Time scan Analysis}

The results of the space-time scan, conducted by absolute number were shown in Fig. 6. From 2009 to 2017, the statistic detected the most likely clusters and secondary clusters and other clusters of the different health workforce, which demonstrated the different growth between inside and outside. Take HT as an example, comparing with the surrounding area, the clusters with high growth tended to be located near the capital, northern Sichuan and southeastern Sichuan throughout research period, while the clusters with lower growth rate were found in were always found in Bazhong, Suining, Yaan, Panzhihua, Liangshanzhou. More information the most likely clusters and other clusters were shown in Table 3. 
Table 3

Space-time analysis of health workforce in Sichuan

\begin{tabular}{|c|c|c|c|c|c|c|c|c|c|c|c|}
\hline $\begin{array}{l}\text { Type of } \\
\text { diseases }\end{array}$ & $\begin{array}{l}\text { Cluster } \\
\text { type }\end{array}$ & Location center & $\begin{array}{l}\text { Cluster } \\
\text { areas }\end{array}$ & Coordinates & $\begin{array}{l}\text { Radius } \\
(\mathrm{Km})\end{array}$ & $\begin{array}{l}\text { Number } \\
\text { of } \\
\text { Cases }\end{array}$ & $\begin{array}{l}\text { Expected } \\
\text { Cases }\end{array}$ & $\begin{array}{l}\text { Annual } \\
\text { Cases/10000 }\end{array}$ & $\begin{array}{l}\text { Relative } \\
\text { Risk }\end{array}$ & $\begin{array}{l}\text { Inside } \\
\text { time } \\
\text { trend }\end{array}$ & $\begin{array}{l}\text { Outsidı } \\
\text { time } \\
\text { trend }\end{array}$ \\
\hline HT & $\begin{array}{l}\text { Most } \\
\text { likely } \\
\text { cluster }\end{array}$ & $\begin{array}{l}\text { Jinjiangqu } \\
\text { (Chengdu) }\end{array}$ & 6 & $\begin{array}{l}30.67 \mathrm{~N} \\
104.08 \mathrm{E}\end{array}$ & 18.28 & 649992 & 183315.39 & 1628.3 & 4.08 & $\begin{array}{l}4.563 \% \\
\text { annual } \\
\text { increase }\end{array}$ & $\begin{array}{l}7.125 \% \\
\text { annual } \\
\text { increas }\end{array}$ \\
\hline HT & $\begin{array}{l}\text { Secondary } \\
\text { cluster }\end{array}$ & $\begin{array}{l}\text { Maerkangshi } \\
\text { (Abazhou) }\end{array}$ & 1 & $\begin{array}{l}31.90 \mathrm{~N} \\
102.22 \mathrm{E}\end{array}$ & 0 & 7148 & 6003.17 & 546.8 & 1.19 & $\begin{array}{l}36.067 \% \\
\text { annual } \\
\text { increase }\end{array}$ & $\begin{array}{l}7.023 \% \\
\text { annual } \\
\text { increas }\end{array}$ \\
\hline HT & $\begin{array}{l}\text { 2nd } \\
\text { secondary } \\
\text { cluster }\end{array}$ & $\begin{array}{l}\text { Enyangqu } \\
\text { (Bazhong) }\end{array}$ & 1 & $\begin{array}{l}31.47 \mathrm{~N} \\
106.37 \mathrm{E}\end{array}$ & 0 & 7308 & 19588.26 & 171.3 & 0.37 & $\begin{array}{l}38.797 \% \\
\text { annual } \\
\text { increase }\end{array}$ & $\begin{array}{l}7.065 \% \\
\text { annual } \\
\text { increas }\end{array}$ \\
\hline HT & $\begin{array}{l}\text { 3rd } \\
\text { secondary } \\
\text { cluster }\end{array}$ & $\begin{array}{l}\text { Qianfengqu } \\
\text { (Guangan) }\end{array}$ & 1 & $\begin{array}{l}30.33 \mathrm{~N} \\
106.49 \mathrm{E}\end{array}$ & 0 & 3175 & 14253.25 & 102.3 & 0.22 & $\begin{array}{l}51.004 \% \\
\text { annual } \\
\text { increase }\end{array}$ & $\begin{array}{l}7.058 \% \\
\text { annual } \\
\text { increas }\end{array}$ \\
\hline HT & $\begin{array}{l}\text { 4th } \\
\text { secondary } \\
\text { cluster }\end{array}$ & $\begin{array}{l}\text { Bazhouqu } \\
\text { (Bazhong) }\end{array}$ & 1 & $\begin{array}{l}31.85 \mathrm{~N} \\
106.77 \mathrm{E}\end{array}$ & 0 & 40041 & 37371.11 & 492.0 & 1.07 & $\begin{array}{l}13.168 \% \\
\text { annual } \\
\text { increase }\end{array}$ & $\begin{array}{l}6.981 \% \\
\text { annual } \\
\text { increas }\end{array}$ \\
\hline HT & \multicolumn{11}{|c|}{ Please see other clusters in Fig. 6} \\
\hline LD & $\begin{array}{l}\text { Most } \\
\text { likely } \\
\text { cluster }\end{array}$ & $\begin{array}{l}\text { Xichangshi } \\
\text { (Liangshanzhou) }\end{array}$ & 1 & $\begin{array}{l}27.90 \mathrm{~N} \\
102.27 \mathrm{E}\end{array}$ & 0 & 38833 & 9727.00 & 751.7 & 4.07 & $\begin{array}{l}13.756 \% \\
\text { annual } \\
\text { decrease }\end{array}$ & $\begin{array}{l}4.144 \% \\
\text { annual } \\
\text { increas }\end{array}$ \\
\hline LD & $\begin{array}{l}\text { Secondary } \\
\text { cluster }\end{array}$ & $\begin{array}{l}\text { Pingwuxian } \\
\text { (Mianyang) }\end{array}$ & 71 & $\begin{array}{l}32.42 \mathrm{~N} \\
104.53 \mathrm{E}\end{array}$ & 258.05 & 853075 & 705507.13 & 227.7 & 1.47 & $\begin{array}{l}4.890 \% \\
\text { annual } \\
\text { increase }\end{array}$ & $\begin{array}{l}2.156 \% \\
\text { annual } \\
\text { increas }\end{array}$ \\
\hline LD & $\begin{array}{l}\text { 2nd } \\
\text { secondary } \\
\text { cluster }\end{array}$ & $\begin{array}{l}\text { Qianfengqu } \\
\text { (Guangan) }\end{array}$ & 1 & $\begin{array}{l}30.33 \mathrm{~N} \\
106.49 \mathrm{E}\end{array}$ & 0 & 1313 & 5843.71 & 42.3 & 0.22 & $\begin{array}{l}44.925 \% \\
\text { annual } \\
\text { increase }\end{array}$ & $\begin{array}{l}3.682 \% \\
\text { annual } \\
\text { increas }\end{array}$ \\
\hline LD & $\begin{array}{l}\text { 3rd } \\
\text { secondary } \\
\text { cluster }\end{array}$ & $\begin{array}{l}\text { Hejiangxian } \\
\text { (Luzhou) }\end{array}$ & 2 & $\begin{array}{l}28.82 \mathrm{~N} \\
105.83 \mathrm{E}\end{array}$ & 37.58 & 32831 & 25894.43 & 238.7 & 1.27 & $\begin{array}{l}6.718 \% \\
\text { annual } \\
\text { increase }\end{array}$ & $\begin{array}{l}3.598 \% \\
\text { annual } \\
\text { increas }\end{array}$ \\
\hline RN & $\begin{array}{l}\text { Most } \\
\text { likely } \\
\text { cluster }\end{array}$ & $\begin{array}{l}\text { Jinjiangqu } \\
\text { (Chengdu) }\end{array}$ & 6 & $\begin{array}{l}30.67 \mathrm{~N} \\
104.08 \mathrm{E}\end{array}$ & 18.28 & 288606 & 69299.67 & 723.0 & 4.97 & $\begin{array}{l}6.642 \% \\
\text { annual } \\
\text { increase }\end{array}$ & $\begin{array}{l}12.286 \\
\text { annual } \\
\text { increas }\end{array}$ \\
\hline RN & $\begin{array}{l}\text { Secondary } \\
\text { cluster }\end{array}$ & $\begin{array}{l}\text { Linshuixian } \\
\text { (Guangan) }\end{array}$ & 48 & $\begin{array}{l}30.33 \mathrm{~N} \\
106.93 \mathrm{E}\end{array}$ & 224.67 & 399814 & 625015.26 & 111.1 & 0.64 & $\begin{array}{l}13.418 \% \\
\text { annual } \\
\text { increase }\end{array}$ & $\begin{array}{l}10.780 \\
\text { annual } \\
\text { increas }\end{array}$ \\
\hline RN & $\begin{array}{l}\text { 2nd } \\
\text { secondary } \\
\text { cluster }\end{array}$ & $\begin{array}{l}\text { Xichangshi } \\
\text { (Liangshanzhou) }\end{array}$ & 1 & $\begin{array}{l}27.90 \mathrm{~N}, \\
102.27 \mathrm{E}\end{array}$ & 0 & 23614 & 8968.84 & 457.1 & 2.66 & $\begin{array}{l}5.331 \% \\
\text { annual } \\
\text { increase }\end{array}$ & $\begin{array}{l}11.667 \\
\text { annual } \\
\text { increas }\end{array}$ \\
\hline $\mathrm{PH}$ & $\begin{array}{l}\text { Most } \\
\text { likely } \\
\text { cluster }\end{array}$ & $\begin{array}{l}\text { Chenghuaqu } \\
\text { (Chengdu) }\end{array}$ & 3 & $\begin{array}{l}30.67 \mathrm{~N} \\
104.10 \mathrm{E}\end{array}$ & 4.91 & 14664 & 3819.80 & 90.7 & 4.07 & $\begin{array}{l}0.055 \% \\
\text { annual } \\
\text { increase }\end{array}$ & $\begin{array}{l}4.340 \% \\
\text { annual } \\
\text { increas }\end{array}$ \\
\hline $\mathrm{PH}$ & $\begin{array}{l}\text { Secondary } \\
\text { cluster }\end{array}$ & $\begin{array}{l}\text { Hongyuanxian } \\
\text { (Abazhou) }\end{array}$ & 15 & $\begin{array}{l}32.80 \mathrm{~N} \\
102.55 \mathrm{E}\end{array}$ & 209.05 & 2202 & 3052.03 & 17.0 & 0.72 & $\begin{array}{l}14.812 \% \\
\text { annual } \\
\text { increase }\end{array}$ & $\begin{array}{l}4.040 \% \\
\text { annual } \\
\text { increas }\end{array}$ \\
\hline $\mathrm{PH}$ & $\begin{array}{l}\text { 2nd } \\
\text { secondary } \\
\text { cluster }\end{array}$ & $\begin{array}{l}\text { Zitongxian } \\
\text { (Mianyang) }\end{array}$ & 4 & $\begin{array}{l}31.63 \mathrm{~N} \\
105.17 \mathrm{E}\end{array}$ & 45.30 & 8885 & 5224.79 & 40.2 & 1.73 & $\begin{array}{l}0.376 \% \\
\text { annual } \\
\text { decrease }\end{array}$ & $\begin{array}{l}4.370 \% \\
\text { annual } \\
\text { increas }\end{array}$ \\
\hline $\mathrm{PH}$ & $\begin{array}{l}\text { 3rd } \\
\text { secondary } \\
\text { cluster }\end{array}$ & $\begin{array}{l}\text { Qionglaishi } \\
\text { (Chengdu) }\end{array}$ & 16 & $\begin{array}{l}30.42 \mathrm{~N} \\
103.47 \mathrm{E}\end{array}$ & 62.55 & 30252 & 16650.03 & 42.9 & 1.97 & $\begin{array}{l}6.500 \% \\
\text { annual } \\
\text { increase }\end{array}$ & $\begin{array}{l}3.728 \% \\
\text { annual } \\
\text { increas }\end{array}$ \\
\hline $\mathrm{PH}$ & $\begin{array}{l}\text { 4th } \\
\text { secondary } \\
\text { cluster }\end{array}$ & $\begin{array}{l}\text { Enyangqu } \\
\text { (Bazhong) }\end{array}$ & 1 & $\begin{array}{l}31.47 \mathrm{~N} \\
106.37 \mathrm{E}\end{array}$ & 0 & 319 & 1007.45 & 7.5 & 0.32 & $\begin{array}{l}44.693 \% \\
\text { annual } \\
\text { increase }\end{array}$ & $\begin{array}{l}4.176 \% \\
\text { annual } \\
\text { increas }\end{array}$ \\
\hline $\mathrm{PH}$ & \multicolumn{11}{|c|}{ Please see other clusters in Fig. 6} \\
\hline TE & $\begin{array}{l}\text { Most } \\
\text { likely } \\
\text { cluster }\end{array}$ & $\begin{array}{l}\text { Jinniuqu } \\
\text { (Chengdu) }\end{array}$ & 4 & $\begin{array}{l}30.70 \mathrm{~N} \\
104.05 \mathrm{E}\end{array}$ & 5.56 & 27715 & 5720.49 & 110.6 & 5.52 & $\begin{array}{l}3.102 \% \\
\text { annual } \\
\text { increase }\end{array}$ & $\begin{array}{l}7.524 \% \\
\text { annual } \\
\text { increas }\end{array}$ \\
\hline TE & $\begin{array}{l}\text { Secondary } \\
\text { cluster }\end{array}$ & $\begin{array}{l}\text { Ruoergaixian } \\
\text { (Abazhou) }\end{array}$ & 15 & $\begin{array}{l}33.58 \mathrm{~N} \\
102.95 \mathrm{E}\end{array}$ & 247.50 & 3364 & 3327.30 & 23.1 & 1.01 & $\begin{array}{l}19.857 \% \\
\text { annual } \\
\text { increase }\end{array}$ & $\begin{array}{l}7.027 \% \\
\text { annual } \\
\text { increas }\end{array}$ \\
\hline
\end{tabular}




\begin{tabular}{|c|c|c|c|c|c|c|c|c|c|c|c|}
\hline $\begin{array}{l}\text { Type of } \\
\text { diseases }\end{array}$ & $\begin{array}{l}\text { Cluster } \\
\text { type }\end{array}$ & Location center & $\begin{array}{l}\text { Cluster } \\
\text { areas }\end{array}$ & Coordinates & $\begin{array}{l}\text { Radius } \\
(\mathrm{Km})\end{array}$ & $\begin{array}{l}\text { Number } \\
\text { of } \\
\text { Cases }\end{array}$ & $\begin{array}{l}\text { Expected } \\
\text { Cases }\end{array}$ & $\begin{array}{l}\text { Annual } \\
\text { Cases/10000 }\end{array}$ & $\begin{array}{l}\text { Relative } \\
\text { Risk }\end{array}$ & $\begin{array}{l}\text { Inside } \\
\text { time } \\
\text { trend }\end{array}$ & $\begin{array}{l}\text { Outsidı } \\
\text { time } \\
\text { trend }\end{array}$ \\
\hline TE & $\begin{array}{l}\text { 2nd } \\
\text { secondary } \\
\text { cluster }\end{array}$ & $\begin{array}{l}\text { Zhaojuexian } \\
\text { (Liangshanzhou) }\end{array}$ & 26 & $\begin{array}{l}28.02 \mathrm{~N}, \\
102.85 \mathrm{E}\end{array}$ & 164.56 & 11342 & 15890.56 & 16.3 & 0.70 & $\begin{array}{l}11.531 \% \\
\text { annual } \\
\text { increase }\end{array}$ & $\begin{array}{l}6.986 \% \\
\text { annual } \\
\text { increas }\end{array}$ \\
\hline TE & $\begin{array}{l}\text { 3rd } \\
\text { secondary } \\
\text { cluster }\end{array}$ & $\begin{array}{l}\text { Tianquanxian } \\
\text { (Yaan) }\end{array}$ & 12 & $\begin{array}{l}30.07 \mathrm{~N}, \\
102.75 \mathrm{E}\end{array}$ & 75.05 & 6839 & 5577.88 & 28.0 & 1.23 & $\begin{array}{l}12.641 \% \\
\text { annual } \\
\text { increase }\end{array}$ & $\begin{array}{l}7.061 \% \\
\text { annual } \\
\text { increas }\end{array}$ \\
\hline $\mathrm{TE}$ & $\begin{array}{l}\text { 4th } \\
\text { secondary } \\
\text { cluster }\end{array}$ & $\begin{array}{l}\text { Qianfengqu } \\
\text { (Guangan) }\end{array}$ & 1 & $\begin{array}{l}30.33 \mathrm{~N}, \\
106.49 \mathrm{E}\end{array}$ & 0 & 148 & 708.69 & 4.8 & 0.21 & $\begin{array}{l}64.536 \% \\
\text { annual } \\
\text { increase }\end{array}$ & $\begin{array}{l}7.236 \% \\
\text { annual } \\
\text { increas }\end{array}$ \\
\hline TE & \multicolumn{11}{|c|}{ Please see other clusters in Fig. 6} \\
\hline IN & $\begin{array}{l}\text { Most } \\
\text { likely } \\
\text { cluster }\end{array}$ & $\begin{array}{l}\text { Wenjiangqu } \\
\text { (Chengdu) }\end{array}$ & 16 & $\begin{array}{l}30.70 \mathrm{~N}, \\
103.83 \mathrm{E}\end{array}$ & 44.48 & 85431 & 48244.12 & 94.1 & 1.96 & $\begin{array}{l}0.309 \% \\
\text { annual } \\
\text { decrease }\end{array}$ & $\begin{array}{l}5.494 \% \\
\text { annual } \\
\text { increas }\end{array}$ \\
\hline IN & $\begin{array}{l}\text { Secondary } \\
\text { cluster }\end{array}$ & $\begin{array}{l}\text { Meiguxian } \\
\text { (Liangshanzhou) }\end{array}$ & 72 & $\begin{array}{l}\text { 28.33N, } \\
103.13 \mathrm{E}\end{array}$ & 234.57 & 122447 & 138094.87 & 47.1 & 0.84 & $\begin{array}{l}7.498 \% \\
\text { annual } \\
\text { increase }\end{array}$ & $\begin{array}{l}3.302 \% \\
\text { annual } \\
\text { increas }\end{array}$ \\
\hline IN & $\begin{array}{l}\text { 2nd } \\
\text { secondary } \\
\text { cluster }\end{array}$ & $\begin{array}{l}\text { Pingchangxian } \\
\text { (Bazhong) }\end{array}$ & 1 & $\begin{array}{l}31.57 \mathrm{~N}, \\
107.10 \mathrm{E}\end{array}$ & 0 & 3509 & 4747.81 & 39.3 & 0.74 & $\begin{array}{l}13.453 \% \\
\text { annual } \\
\text { decrease }\end{array}$ & $\begin{array}{l}4.620 \% \\
\text { annual } \\
\text { increas }\end{array}$ \\
\hline IN & $\begin{array}{l}\text { 3rd } \\
\text { secondary } \\
\text { cluster }\end{array}$ & $\begin{array}{l}\text { Cangxixian } \\
\text { (Guangyuan) }\end{array}$ & 17 & $\begin{array}{l}31.72 \mathrm{~N}, \\
105.93 \mathrm{E}\end{array}$ & 106.53 & 53021 & 54769.90 & 51.4 & 0.96 & $\begin{array}{l}9.201 \% \\
\text { annual } \\
\text { increase }\end{array}$ & $\begin{array}{l}3.819 \% \\
\text { annual } \\
\text { increas }\end{array}$ \\
\hline IN & $\begin{array}{l}\text { 4th } \\
\text { secondary } \\
\text { cluster }\end{array}$ & $\begin{array}{l}\text { Qianfengqu } \\
\text { (Guangan) }\end{array}$ & 1 & $\begin{array}{l}30.33 \mathrm{~N}, \\
106.49 \mathrm{E}\end{array}$ & 0 & 616 & 1649.15 & 19.8 & 0.37 & $\begin{array}{l}55.328 \% \\
\text { annual } \\
\text { increase }\end{array}$ & $\begin{array}{l}4.450 \% \\
\text { annual } \\
\text { increas }\end{array}$ \\
\hline
\end{tabular}

\section{Discussion}

This research performed a comparative spatio-temporal analysis of health workforce (HT, LD, RN, pharmacist, technologist, and intern) in the Sichuan province of China, which produced much evidence for formulating and promulgating policies and adopting strategies of human resources attraction and retention based on time and space. We would like to explore the spatio-temporal analysis of different health workforce and then lay special stress on discussing future strategic planning and policy development.

In general, China is always conforming severe problems such as scarcity of qualified HT [43, 44], uneven distribution of health workforce [45], so is Sichuan. There were several reasons explaining the situation like the unbalanced development among regions, such as the tension between doctors and patients [46, 47], the huge economic and social difference between regions. The research displayed the problems in a systematic way and manage to find effective methods to tackle it. On the whole, the global Moran's I of the number per 1000 population of health workforce in Sichuan all reached the 0.001 significance level in the whole research period, demonstrating the spatial agglomeration among all the health human resources, which strengthened our argument about issue of misdistribution and supported part previous studies. Obviously, the spatio-temporal characteristics of HT, LD, RN, pharmacist, technologist, and intern in Sichuan remained different in trends, hotspots, clusters and changing patterns.

On the one hand, the HT contained the other health workforce in our analysis. We would like taking a look at it first. The absolute number increased from 303051 to 530306 in nine years, the average annual growth rate is $7.24 \%$, which also could be acquired by the temporal analysis. According to the previous analysis, the average annual growth rate of China is $6.25 \%$ during the research period, while the number is $5.43 \%, 6.20 \%$ and $7.24 \%$ respectively in Beijing (Eastern China), Hubei (Middle China) and Ningxia (Western China). By the end of 2018, the number of HT in Sichuan province accounted for only $5.90 \%$ of the total number of HT in China. Zhang found the number per 1000 population of the different health workforce is increasing year by year [48], the same results were discovered by Xiao and $\mathrm{He}[49,50]$. When it comes to spatial analysis, on the one hand, to our surprise, the citizens tend to believe there is lack of health human resources in Qinghai Tibet Plateau, however, according to our study, the HT is probably the thing that Sichuan has least in Tsinling Mountains, Yunnan-Guizhou Plateau, Hengduan Mountains and the transition zone of mountains and basins. The LL cluster and the most like cluster areas echoed and supported the result. In contrast, the analysis of the number of per square kilometres told difference. The distribution of HT is strictly negatively correlated with areas. Qinghai Tibet Plateau is confronted with a scarcity of HT. On the other hand, the resource-rich areas were the capital Chengdu and the city of iron and steel Panzhihua. The HH cluster and most likely cluster area demonstrated our findings. The economic state, population, geomorphological type and area of units were important determinants of shortage and uneven distribution of health workforce. In recent years, Chengdu and Panzhihua depended on a high salary, career development and quality of life to attract and retain HT. At the same time, the special minority policies in China tend to encourage health workforce to stay in minority area such as Qinghai Tibet Plateau, while from the perspective of population and area of units, the eastern areas had a relatively large population and small areas, which all the special circumstances were going unnoticed.

On the other hand, LD and RN were the core of HT, which would be analyzed separately. The absolute number of LD went up from 97070 to 126634 with an average annual growth rate of $3.38 \%$ from 2009 to 2017 , while the number is $6.78 \%, 5.60 \%$ and $5.36 \%$ in Beijing, Hubei, and Ningxia. As to RN, the absolute number increased from 55532 to 143314 with an average annual growth rate of $12.58 \%$, which number is $9.04 \%, 9.84 \%$, and $10.30 \%$. The number per 1000 
population of LD and RN was 2.34 and 2.77. According to data of the World Bank WDI Database in 2018, the physicians per 1000 population in high-income countries is $3.0[51,52]$. Sichuan still needed to take various measures in attracting doctors. Sichuan province did a relatively satisficed job in attracting and retaining nurses. The overall construction of nursing human resources in Sichuan Province had been improved, but the ratio of doctors and nurses was far short of what is required of 1:2 in the trial draft of organization budgeting principles on Comprehensive Hospital personnel issued by the National Health Commission of the PRC [53]. As to spatial analysis, the shortage of LD and RN was exposed to western and eastern areas. Our research is comparative, so compared with the rich place, the plateau and mountain areas were still lack resources. Furthermore, except for sufficient resources in capital and rich place, some core areas of poor territories exhibited adequate resources, as shown in LL and HH cluster map. As to the RN, Cao applied the Gini coefficient and Thiel index to assess the equity of Sichuan, discovering the number per 1000 population of RN in Chengdu, Panzhihua, Zigong, Luzhou and Yaan was higher than average level of Sichuan, which was similar with our results [54]. The uneven distribution was discovered in two levels, the capital and rich snatched resources from other areas, while the core area in poor place attracted health workforce from other places, which is in accordance with the law of development.

Furthermore, pharmacist and technologist were important parts of health workforce. According to our analysis, the temporal trend remained constant upward. The spatial distribution is similar with another health workforce with the HH cluster in Chengdu and Panzhihua, while LL clusters were found in eastern areas. The related research was quite rare. Li conducted research about the pharmacist in China, discovering Zhejiang, Jiangsu, Guangdong, Shandong, and Shanghai are the top five provinces in the number of pharmacist in China [55]. The above five provinces are in the eastern region, accounting for $38 \%$ of the total number of pharmacist in China. The number of pharmacist is relatively deficient in Xizang, Qinghai, Ningxia, Heilongjiang, and Hainan. Sichuan is in the middle [56]. Nowadays, China had an ample number of pharmacist. From 2009 to 2017, the number of pharmacist has increased year by year. However, due to the backward legislation of pharmacist and lacking a clear system for the allocation and use of pharmacist, the curve of the number of pharmacist in China is rising slowly. According to some interviews we conducted in the village, the technologist was rare in some places, which led to no professional and qualified technologist to use the medical equipment.

Interestingly, interns displayed quiet unique characteristics comparing with others. The absolute number of interns went up from 28614 to 41050 with an average annual growth rate of $4.61 \%$ from 2009 to 2017 . However, the spatial distribution was totally different from another health workforce. The Qinghai Tibet Plateau and capital had the highest number per 1000 population, as shown in the hierarchical map and cluster map. In order to improve the health human workforce in poor areas, the Chinese government required interns to work in relatively remote and poor territories before becoming a practicing physician. The policy had a limited effect in dealing with the misdistribution in health workforce.

To conclude, four main findings should be pay attention to: the whole health workforce of Sichuan province had an upward trend. Comparing with other province, the growth rate was relatively high; the areas with the scarcest resources were eastern places, including Tsinling Mountains, Yunnan-Guizhou Plateau, Hengduan Mountains and the transition zone of mountains and basins; misdistribution of health workforce had two levels, among the province and cities; the Qinghai Tibet Plateau has enough interns, while being short of other HT.

As to the limitation of the research, this study displayed simplification of indicator. More indicators should be include; the spatial analysis reflected the comparative results, so the classification of hierarchical and cluster maps only displayed relative situation of health workforce; only the case of Sichuan is not enough to extend to the whole country, other units should take specific economic and social conditions into account when formulating corresponding policies.

\section{Conclusions}

There are still a lot of tremendous obstacles in dealing with the problem of scarcity and misdistribution in order to achieve health equity in Sichuan. According to the temporal and spatial analysis conducted in our study, the policies makers should pay more attention to the eastern Sichuan, which had much more population but less health workforce. As to the intern-related policies, the primary health tasks did not achieve, the government in Qinghai Tibet Plateau areas needed to find more practical ways like higher income, better career development to hold the interns. We believe the most effective way to address the problem is networking, artificial intelligence, computer-aided engineering, and manufacturing. The better resources of health workforce would be shared through the internet.

\section{Abbreviations}

WHO: World Health Organization; UN: the United Nations; SDGs: Sustainable development goals; HT: health technicians; LD: licensed doctors; RN: registered nurses; PH: pharmacists; TE: technologists; IN: interns; HH: High-high; HL: High-low; LH: Low-high; LL: Low-low; RR: Relative risk; LLR: Log Likelihood Ratio; USA: The United States; WA: Washington; NY: New York; CA: California; MA: Massachusetts; IL: Illinois; IBM: International Business Machines Corporation; ESRI: Environmental Systems Research Institute; IQR: interquartile range;

\section{Declarations}

\section{Ethics approval and consent to participate}

Not applicable

\section{Consent for publication}

Not applicable

\section{Availability of data and materials}


All data generated or analyzed during this study are included in this published article [and its supplementary information files]

\section{Competing interests}

The authors declare that they have no competing interests.

\section{Funding}

The study was funded by the Major Project of National Social Science Fund of China: Research on big health putting prevention first and construction of healthy China (grant number 17ZDA079). The funder had no role in the study design, data collection and analysis, interpretation of data, and writing the manuscript.

\section{Authors' contributions}

NZ, JLL and YM conceived and designed the study; NZ and RXH collected and analyzed the data; NZ, BZ, WN and TX drafted the paper, NZ, XW and YM read and revised the draft critically. All authors read and approved the final manuscript.

\section{Acknowledgements}

The authors would like to thank the National Social Science Fund of China for its support and the Health Commission of Sichuan Province for sharing the valuable data.

\section{References}

1. WHO Consultative Group on Equity and Universal Health Coverage. Making fair choices on the path to universal health coverage: Final report of the WHO Consultative Group on Equity and Universal Health Coverage. Health Econ Policy Law. 2014.

2. Hosseinpoor AR, Bergen N, Schlotheuber A. Promoting health equity: WHO health inequality monitoring at global and national levels. Glob Health Action. 2015.

3. Health Professions Network Nursing and Midwifery Office Department of Human Resources for Health. Human Resources for Health Framework for Action on Interprofessional Education \& Collaborative Practice. World Heal Organ. 2010.

4. Campbell J, Buchan J, Cometto G, David B, Dussault G, Fogstad H, et al. Human resources for health and universal health coverage: fostering equity and effective coverage. Bull World Health Organ. 2013.

5. World Health Organization. Optimizing health worker roles to improve access to key maternal and newborn health interventions through task shifting. World Heal Organ. 2012.

6. WHO. Reassessing the relationship between human resources for health, intervention coverage and health outcomes. Genova, Switherland; 2006.

7. World Health Organization. Monitoring the Building Blocks of Health Systems: a Handbook of Indicators and Their Measurement Strategies. 2010.

8. Cylus J, Richardson E, Findley L, Longley M, O’Neill C, Steel D. United Kingdom: Health System Review. Health Syst Transit. 2015.

9. Crettenden IF, McCarty M V., Fenech BJ, Heywood T, Taitz MC, Tudman S. How evidence-based workforce planning in Australia is informing policy development in the retention and distribution of the health workforce. Hum Resour Health. 2014.

10. Vives A, Vanroelen C, Amable M, Ferrer M, Moncada S, Llorens C, et al. Employment precariousness in Spain: Prevalence, social distribution, and population-attributable risk percent of poor mental health. Int J Heal Serv. 2011.

11. Tangcharoensathien V, Limwattananon S, Suphanchaimat R, Patcharanarumol W, Sawaengdee K, Putthasri W. Health workforce contributions to health system development: a platform for universal health coverage. Bull World Health Organ. 2013.

12. Van Rensburg HCJ. South Africa's protracted struggle for equal distribution and equitable access - still not there. Human Resources for Health. 2014.

13. Sousa A, Dal Poz MR, Carvalho CL. Monitoring inequalities in the health workforce: The case study of brazil 1991-2005. PLoS One. 2012.

14. Hazarika I. Health workforce in India: assessment of availability, production and distribution. WHO South-East Asia J Public Heal. 2013.

15. Kurniati A, Rosskam E, Afzal MM, Suryowinoto TB, Mukti AG. Strengthening Indonesia's health workforce through partnerships. Public Health. 2015.

16. Tandi TE, Cho Y, Akam AJC, Afoh CO, Ryu SH, Choi MS, et al. Cameroon public health sector: Shortage and inequalities in geographic distribution of health personnel. Int J Equity Health. 2015.

17. Chen R, Zhao Y, Du J, Wu T, Huang Y, Guo A. Health workforce equity in urban community health service of China. PLoS One. 2014.

18. Anand S, Fan VY, Zhang J, Zhang L, Ke Y, Dong Z, et al. China's human resources for health: quantity, quality, and distribution. The Lancet. 2008.

19. Ren Y, Qian P, Duan Z, Zhao Z, Pan J, Yang M. Disparities in health system input between minority and non-minority counties and their effects on maternal mortality in Sichuan province of western China. BMC Public Health. 2017.

20. Xie X, Liu P, Zheng Y, Zhou W, Zou J, Wang X, et al. Equity of health resource distribution in China during 2009-15: an analysis of cross-sectional nationwide data. Lancet. 2017.

21. Zhu B, Hsieh CW, Zhang Y. Incorporating spatial statistics into examining equity in health workforce distribution: An empirical analysis in the Chinese context. Int J Environ Res Public Health. 2018.

22. Liu J, Mao Y. Does previous job mobility behaviour have an effect on current turnover intentions of rural nurses? A cross-sectional survey in western China. Lancet. 2019. 
23. Liu J, Zhu B, Wu J, Mao Y. Job satisfaction, work stress, and turnover intentions among rural health workers: a cross-sectional study in 11 western provinces of China. BMC Fam Pract. 2019.

24. Liu J, Mao Y. Patient satisfaction with rural medical services: A cross-sectional survey in 11 Western Provinces in China. Int J Environ Res Public Health. 2019.

25. HuiWen X, WeiJun Z, XiuLan Z, ZhiYong Q, XiaoHua W, ZhiHong S, et al. Longitudinal study of rural health workforce in five counties in China: research design and baseline description. Hum Resour Health. 2013.

26. Zhu B, Fu Y, Liu J, Mao Y. Modeling the dynamics and spillovers of the health labor market: Evidence from China's provincial panel data. Sustain. 2018.

27. PRC NHC. China health statistical Yearbook 2017. Chinese Peking Union Medical College Press. 2017.

28. Li L, Fu H. China's health care system reform: Progress and prospects. Int J Health Plann Manage. 2017.

29. Krzywinski M, Altman N. Visualizing samples with box plots. Nat Methods. 2014.

30. McGill R, Tukey JW, Larsen WA. Variations of box plots. Am Stat. 1978.

31. Fischer MM, Griffith DA. Modelling Spatial Autocorrelation in Spatial Interaction Data. SSRN Electron J. 2011.

32. Griffith DA, Fischer MM, LeSage J. The spatial autocorrelation problem in spatial interaction modelling: a comparison of two common solutions. Lett Spat Resour Sci. 2017.

33. Zhu B, Hsieh CW, Mao Y. Addressing the licensed doctor Maldistribution in china: A demand-and-supply perspective. Int J Environ Res Public Health. 2019.

34. Zhu B, Fu Y, Liu J, Mao Y. Spatial distribution of 12 class B notifiable infectious diseases in China: A retrospective study. PLoS One. 2018.

35. Wrigley N, Cliff AD, Ord JK. Spatial Processes: Models and Applications. Geogr J. 1982.

36. Cliff A, Ord K. Testing for Spatial Autocorrelation Among Regression Residuals. Geogr Anal. 1972.

37. Anselin L. Local Indicators of Spatial Association-LISA. Geogr Anal. 1995.

38. Anselin L. Global spatial autocorrelation. Spat Anal Course. 2008.

39. SaTScan. SaTScan - Software for the spatial, temporal, and space-time scan statistics. https://www.satscan.org/. 2005.

40. Kulldorff M. Prospective time periodic geographical disease surveillance using a scan statistic. J R Stat Soc Ser A Stat Soc. 2001.

41. Kulldorff M, Heffernan R, Hartman J, Assunção R, Mostashari F. A space-time permutation scan statistic for disease outbreak detection. PLoS Med. 2005.

42. Kulldorff M, Athas WF, Feuer EJ, Miller BA, Key CR. Evaluating cluster alarms: A space-time scan statistic and brain cancer in Los Alamos, New Mexico. Am J Public Health. 1998.

43. World Health Organisation. Density of physicians (total number per 1000 population, latest available year). WHO. 2016.

44. Song F, Rathwell T, Clayden D. Doctors in China from 1949 to 1988. Health Policy Plan. 1991.

45. Zhou K, Zhang X, Ding Y, Wang D, Lu Z, Yu M. Inequality trends of health workforce in different stages of medical system reform (1985-2011) in China. Hum Resour Health. 2015.

46. Ma S, Xu X, Trigo V, Ramalho NJC. Doctor-patient relationships (DPR) in China. J Health Organ Manag. 2017.

47. The Lancet. Protecting Chinese doctors. Lancet. 2020;395:90. doi:10.1016/S0140-6736(20)30003-9.

48. Ruihua Z, Daren Z, Zhihui L, Sichang H, Boxing S. Study on Current Situation and Forecast of Health Human Resource Allocation in Sichuan Province. Med Soc (Berkeley). 2016;29:58-61.

49. Hong J. Ahalysis and Countermeasares of Human Resources in Public Hospital at County Level in Sichuan Province. Sichuan Med J. 2015;36.

50. Sichang H, Zhihui L, Daren Z, Boxing S, Ruihua Z, Jiaoyue L, et al. Analysis on the Conifgurin g Fairness Human Resources for Health Based on Clusters of Three Regions of Sichuan. Chinese Prim Heal Care. 2016;30:7-10.

51. United Nations-World Bank. World Development Indicators (WDI) | Data Catalog. Data Catalog, United Nations World Data bank. 2018.

52. WHO. The world health report 2013: Research for universal health coverage. World Heal Organ Press. 2013.

53. Junye T, Jing L, Meihua H, Huijuan L, Yanming D. Research progress on allocation and usage of nursing human resource in hospital. Chinese Nurs Manag. 2014;14:1300-4.

54. Qing C. Status Quo and Equity of Allocation of Human Resources of Nursing in Sichuan Province. Med Soc (Berkeley). 2019;32:40-3.

55. Zhaohui L, Jinhuan D, Liya C. Analysis on the distribution of licensed pharmacists in China in 2011. Chian Pharm. 2012;15:881-3.

56. Zhaohui L, Jinhuan D, Liya C. Analysis on the Distribution of Licensed Pharmacists in China. China Pharm. 2012;15:881-3.

\section{Additional Files}

Additional file 1: Growth of the number of health workforce per 1000 population in China;

Additional file 2: The specific classification of health workforce;

Additional file 3: The population of counties in Sichuan province;

Additional file 4: The number of health workforce in Sichuan province at the municipal level;

Additional file 5: The number of health workforce in county-level;

Additional file 6: The $\mathrm{p}$-value results for chi-square linear by linear association test;

Page $13 / 17$ 


\section{Figures}

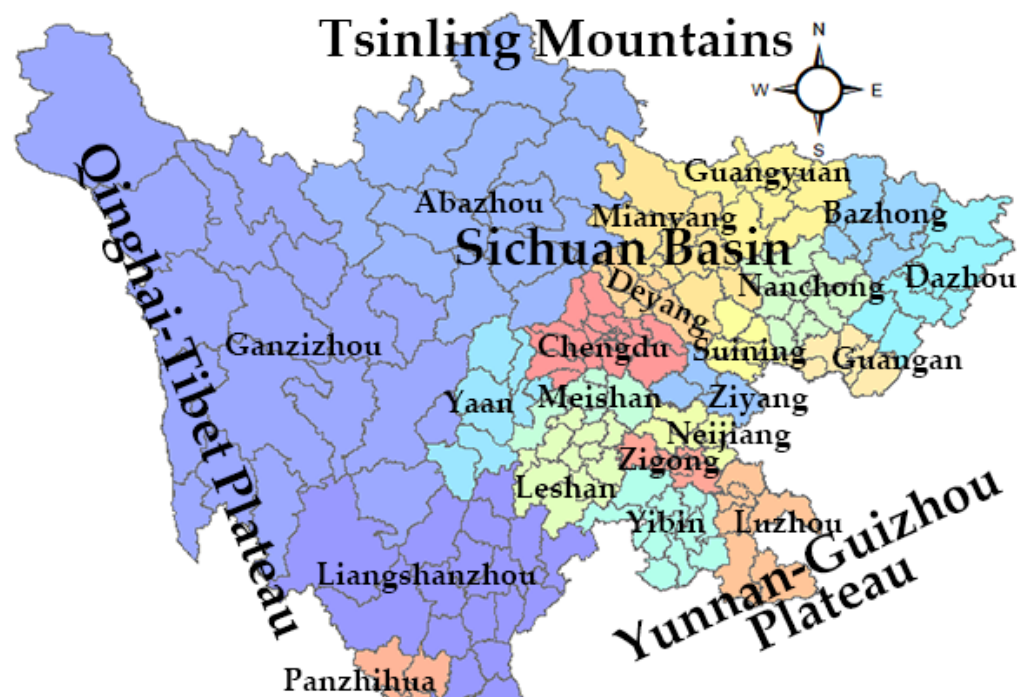

\section{Hengduan Mountains}

Figure 1

The map of Sichuan. Note: The designations employed and the presentation of the material on this map do not imply the expression of any opinion whatsoever on the part of Research Square concerning the legal status of any country, territory, city or area or of its authorities, or concerning the delimitation of its frontiers or boundaries. This map has been provided by the authors.

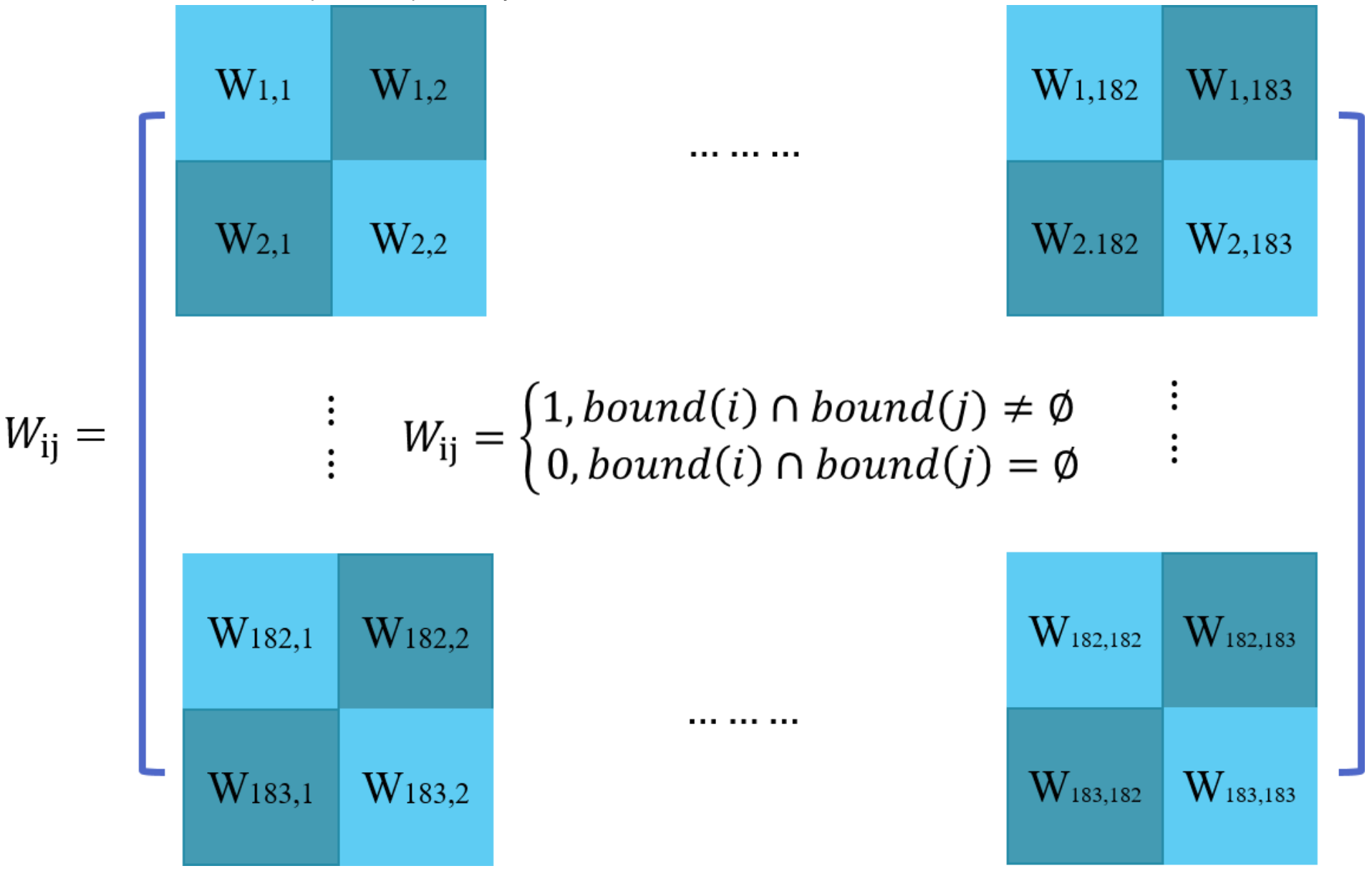

Figure 2

The spatial weight matrix. 


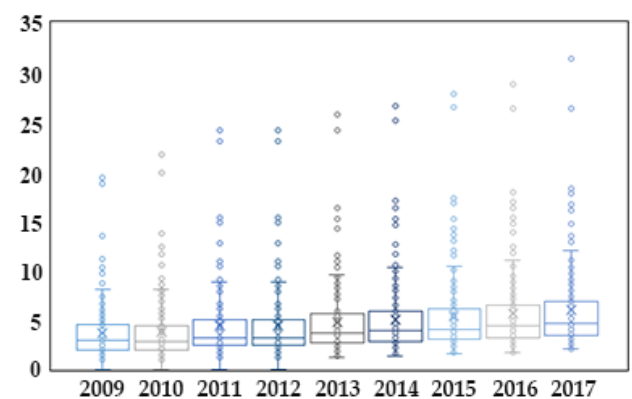

HT

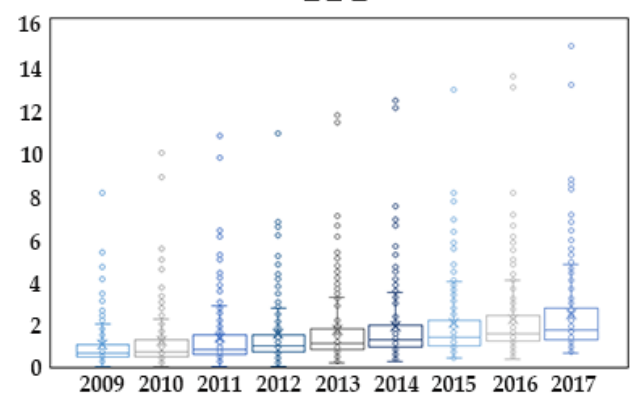

RN

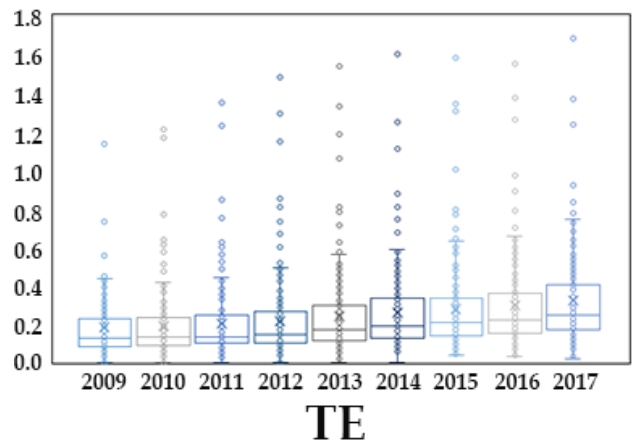

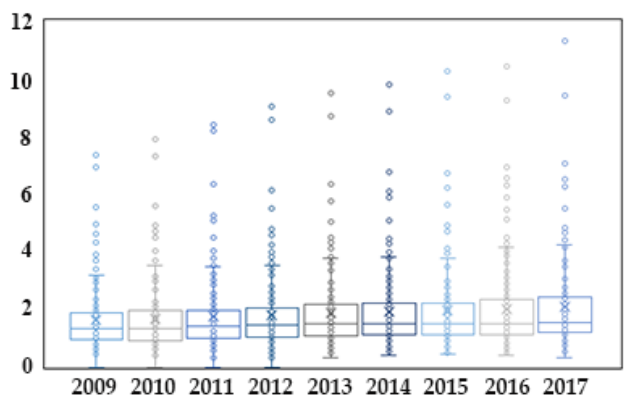

LD
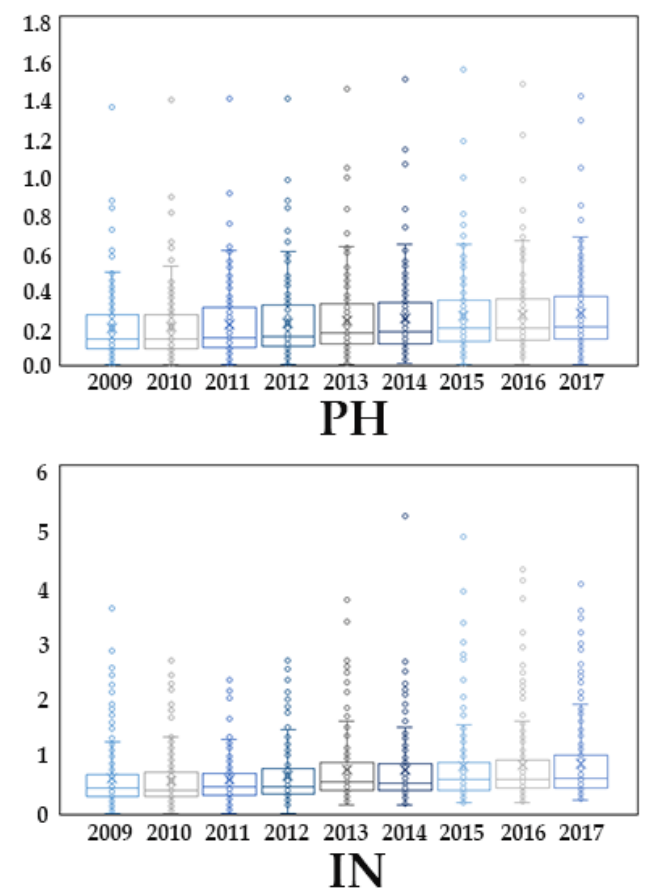

\section{Figure 3}

Box plots of number per 1000 population of different types of health workforce from 2009 to 2017 .

屏

Figure 4

The hierarchy maps of the number per 1000 population of the health workforce of all types of health workforce in 2009,2013 , and 2017 . Note: The designations employed and the presentation of the material on this map do not imply the expression of any opinion whatsoever on the part of Research Square concerning the legal status of any country, territory, city or area or of its authorities, or concerning the delimitation of its frontiers or boundaries. This map has been provided by the authors. 


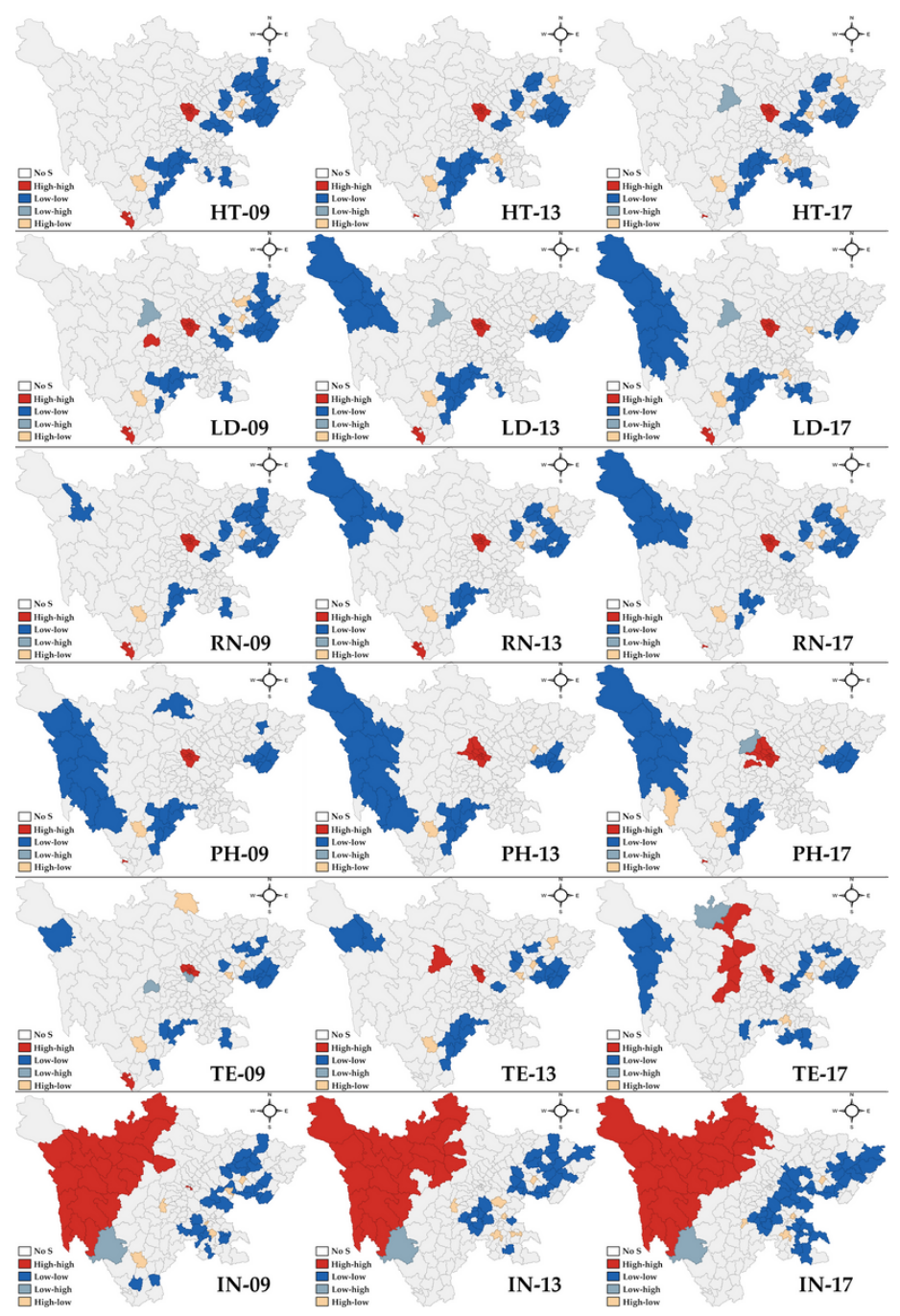

Figure 5

Spatial clusters of all type of health workforce in 2009, 2013, and 2017. Note: The designations employed and the presentation of the material on this map do not imply the expression of any opinion whatsoever on the part of Research Square concerning the legal status of any country, territory, city or area or of its authorities, or concerning the delimitation of its frontiers or boundaries. This map has been provided by the authors. 


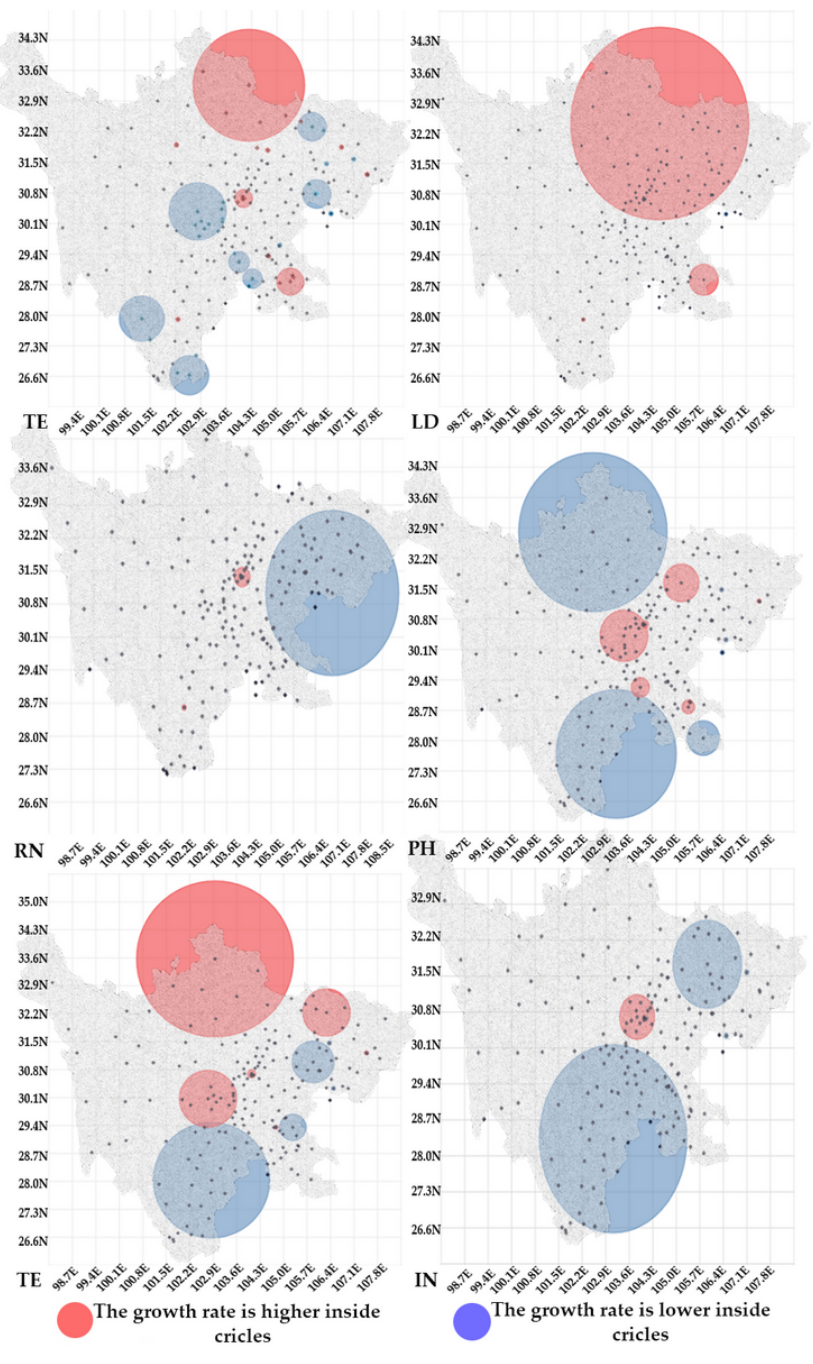

\section{Figure 6}

The spatial-temporal clusters detected by the space-scan statistics. Note: The designations employed and the presentation of the material on this map do not imply the expression of any opinion whatsoever on the part of Research Square concerning the legal status of any country, territory, city or area or of its authorities, or concerning the delimitation of its frontiers or boundaries. This map has been provided by the authors.

\section{Supplementary Files}

This is a list of supplementary files associated with this preprint. Click to download.

- Additionalfile3.xIsx

- Additionalfile5.xIsx

- Additionalfile7.doc

- Additionalfile4.xIsx

- Additionalfile1.docx

- Additionalfile2.doc

- Additionalfile6.docx 